ISSN 1392-3196 / e-ISSN 2335-8947

Zemdirbyste-Agriculture, vol. 100, No. 4 (2013), p. 393-400

DOI 10.13080/z-a.2013.100.050

\title{
Weevil (Coleoptera: Curculionidae) assemblages in the fields of narrow-leafed lupin sown as pure stand and intercropped with spring triticale
}

\author{
Michał HUREJ, Jacek Piotr TWARDOWSKI, Marcin KOZAK \\ Wrocław University of Environmental and Life Sciences \\ Grunwaldzka 24A, 50-363 Wrocław, Poland \\ E-mail: michal.hurej@up.wroc.pl
}

\begin{abstract}
Intercropping is an important cultural practice in pest management and is based on the principle of reducing insect pests by increasing the diversity of an ecosystem. The aim of the study was to determine the abundance and species composition of weevil assemblages noted in the fields of narrow-leafed pure stands lupin and lupin intercropped with spring triticale. Weevils (Coleoptera: Curculionidae) in mixed crops were studied at Wrocław University of Environmental and Life Sciences, Poland, in 2010-2012. The experiment was designed as a split-plot with four replicates for each mixture of plants. Lupin and triticale were sown at three different proportions. The abundance of adult weevils was recorded using pitfall traps. The feeding damage caused by adult beetles on lupin plants was monitored weekly. Weevils were more numerous in the pure stands of lupin than in those intercropped with triticale. Usually more species were found in the pure stands of lupin than in mixtures. In each year, the dominant species in all the three treatments was Charagmus griseus. Sitona macularius and Ch. gressorius were also abundant. The seasonal fluctuations of the number of notches caused by weevils on the leaf margins were similar in all treatments, irrespective of the lupin seed ratio in the intercropping system.
\end{abstract}

Key words: lupin, mixed crops, pest, species composition, Triticosecale.

\section{Introduction}

The single-species nature of crop systems can be broken by growing crops in polycultural patterns. Intercropping which is a narrower category of polyculture is the agronomic practice of growing two or more crops in the same field at the same time (Andrews, Kassam, 1976). Interactions between different plants may have inhibiting or stimulatory effects on plant fitness and yield stability (Lithourgidis et al., 2011; Ratnadass et al., 2012; Tooker, Frank, 2012). In the design and management of these systems, one strategy is to minimize competition and maximize complementation among plant species. The potential advantages that can emerge from the intelligent design of multiple cropping are the suppression of weeds through shading by complex canopies or allelopathy, the better use of soil nutrients, and the improvement of productivity per unit of land (Altieri, Letourneau, 1982). Intercropping is also an important cultural practice in pest management. It is based on the principle of reducing insect pests by increasing the diversity of an ecosystem (Andow, 1991; Altieri, 1999; Smith, McSorley, 2000; Risch, 2005; Moonen, Bàrberi, 2008). Interactions between component crops make intercropping systems more complex and at the same time frequently reduce pest attack. Overwhelming evidence suggests that polycultures support a lower herbivore load than monocultures, predominantly among the food specialists (Vandermeer, 1989). In fields with a mixture of crops a given pest will find fewer acceptable hosts to feed or lay eggs in comparison to fields with a single crop. However, reviews of the literature indicate that insects that have a broad host range may not be reduced by diversifying crops (Andow, 1991). In contrast, polyphagous species often fared better and exhibited higher densities in polycultures. Hurej and Twardowski (2003) showed that intercropping of yellow lupin (Lupinus luteus L. cv. 'Markiz') with spring triticale (cv. 'Wanad') decreased pest population feeding on legume plants. The greatest reducing effect was observed in the case of the black bean aphid Aphis fabae Scopoli and partially in the case of thrips (Thysanoptera). In the same trials, carabid beetles (Coleoptera: Carabidae) were most numerous in yellow lupin grown as a single crop and in lupin intercropped with spring triticale where the proportion of lupin was the highest (Hurej, Twardowski, 2006).

From Curculionidae family, especially the sitona weevils (Sitona spp.) feed on a range of annual and perennial legume species and some of them are serious agricultural pests (Petrukha, 1970; Pisarek, $2001 \mathrm{a}$; b). Unfortunately, only few studies concerning damage by lupin weevils on lupin plants have been published so far. 
Silva and De Oliveira (1959) reported infestation rates of $80-100 \%$ on Lupinus luteus in Portugal and observed considerable yield loss due to insect infestation. In Germany, the grain yield in L. angustifolius was strongly reduced (up to $40 \%$ ) by insects including lupin weevils (Strocker et al., 2011). Infestation by weevils was higher in genotypes of L. angustifolius than in L. luteus. To date no studies on any weevils feeding on lupin grown in mixture with cereals have been conducted in Poland. In the available world literature there are also no data concerning this problem.

Based on the potential positive effects which can be obtained from intercropping according to information given above the aim of the study was to determine the abundance and species composition of weevil assemblages noted on fields with narrow-leafed pure stands of lupin (Lupinus angustifolius L.) and lupin intercropped with spring triticale ( $\times$ Triticosecale Wittm.).

\section{Materials and methods}

Weevils in the intercropping of narrow-leafed lupin (cv. 'Graf') with spring triticale (cv. 'Dublet') were studied at the Experimental Research Station at Pawłowice near Wrocław, Lower Silesia, Poland, during three seasons (2010-2012). The mixtures and the pure stands of lupin were grown in plots of $15 \mathrm{~m}^{2}(10 \mathrm{~m} \times 1.5 \mathrm{~m})$ on sandy soil. The $0.3 \mathrm{~m}$ wide space between the experimental plots was maintained mechanically as a bare soil. The experiment was designed as a split-plot with four replicates for each mixture of plants. Lupine and triticale were sown at three different proportions (Table 1).

Table 1. Number of narrow-leafed lupin and spring triticale seeds sown per $1 \mathrm{~m}^{2}$ in the different treatments of the experiment

\begin{tabular}{cccc}
\hline Treatment & $\begin{array}{c}\text { Narrow-leafed } \\
\text { lupin }\end{array}$ & $\begin{array}{c}\text { Spring } \\
\text { triticale }\end{array}$ & $\begin{array}{c}\text { \% of narrow- } \\
\text { leafed lupin seed } \\
\text { in mixture }\end{array}$ \\
\hline A & 100 & 0 & 100 \\
B & 60 & 160 & 27 \\
C & 40 & 240 & 14 \\
\hline
\end{tabular}

In the pure stand of lupin, 100 seeds per $1 \mathrm{~m}^{2}$ were sown, as recommended by the breeder. Further variants of lupin seed rate were systematically reduced by $40 \%$ and $60 \%$, compared to the pure stand. In the case of triticale, the optimal number of seeds was 400 per $1 \mathrm{~m}^{2}$ in pure stand (not included in this study) and it steadily decreased with the increasing lupine planting rate. The various mixed cropping systems were also analyzed for their suitability as ruminant feed. Therefore, such a system ensures the opportunity to study a multivariate assessment of lupine and triticale seed yield, taking also into account the total protein yield from 1 ha. Thousand seed weight of narrow-leafed lupin was $145 \mathrm{~g}$ and it was $38.7 \mathrm{~g}$ in the case of spring triticale. Germination rate of the seeds of both plant species was $95 \%$. In all treatments of the research area, the same level of mineral fertilization before sowing was applied per 1 ha $\left(\mathrm{P}_{2} \mathrm{O}_{5}-\right.$ $60 \mathrm{~kg}, \mathrm{~K}_{2} \mathrm{O}-120 \mathrm{~kg}$ and $\mathrm{N}-30 \mathrm{~kg}$ ). Maize cultivated for grain was the forecrop. There were no pesticides used in this research due to the lack of products registered for this type of mixed crops in Poland.

The abundance of adult weevils was recorded using plastic pitfall traps. One trap was located in the middle of each plot (four traps per treatment). The diameters of the plastic traps were $9 \mathrm{~cm}$ and they were sunk into the top layer of soil, with the rim at the soil surface. Traps were filled with 50:50 water and ethylene glycol as preservative. They were emptied weekly from the end of April $(2010,2011)$ or beginning of May (2012) to the last ten days of July, which covered the period from the beginning of emergence until the full maturity of lupin plants. The feeding damage caused by adult beetles, i.e. the characteristic notches on the lupin leaf margins were counted weekly on 10 consecutive plants in the middle row of each plot.

For comparison of the number of weevils collected with pitfall traps in three different treatments of the experiment as well as number of notches on the leaf margins caused by weevils on narrow-leafed lupin the analysis of variance (ANOVA) followed by Tukey's HSD (post-hoc) were used. Statistical significance was evaluated at $P \leq 0.05$. For analysis Statistica 9.0 was chosen. To avoid the influence of seasonal trends, statistical analyses were calculated separately for each date.

Meteorological conditions. Meteorological data were collected from electronic data loggers located 20 $\mathrm{cm}$ above ground, directly within the experimental plots. Temperature $\left({ }^{\circ} \mathrm{C}\right)$ and relative air humidity $(\%)$ were measured at intervals of 15 minutes, during the whole growing season (Table 2). No apparent differences in the weather conditions between particular seasons were

Table 2. Meteorological conditions during the growing seasons 2010-2012

\begin{tabular}{|c|c|c|c|c|c|c|c|c|c|}
\hline \multirow{3}{*}{ Years } & \multicolumn{9}{|c|}{ Months and ten-day periods } \\
\hline & \multirow{2}{*}{$\begin{array}{c}\text { April } \\
\text { III }\end{array}$} & \multicolumn{3}{|c|}{ May } & \multicolumn{3}{|c|}{ June } & \multicolumn{2}{|c|}{ July } \\
\hline & & I & II & III & I & II & III & I & II \\
\hline \multicolumn{10}{|c|}{ Temperature ${ }^{\circ} \mathrm{C}$} \\
\hline 2010 & 15.6 & 14.1 & 12.2 & 17.0 & 19.9 & 18.6 & 20.2 & 22.6 & 26.1 \\
\hline 2011 & 16.6 & 12.1 & 18.1 & 20.7 & 23.7 & 21.9 & 20.9 & 19.5 & 21.9 \\
\hline 2012 & 23.6 & 17.7 & 15.1 & 21.8 & 16.9 & 21.2 & 21.3 & 25.6 & \\
\hline \multicolumn{10}{|c|}{ Relative humidity $\%$} \\
\hline 2010 & 54.1 & 77.9 & 86.5 & 78.0 & 80.0 & 75.8 & 68.4 & 67.5 & 69.8 \\
\hline 2011 & 56.2 & 64.1 & 66.8 & 63.7 & 60.6 & 64.5 & 66.2 & 76.0 & 72.0 \\
\hline 2012 & 50.1 & 69.2 & 62.2 & 53.6 & 73.4 & 73.4 & 71.8 & 68.3 & \\
\hline
\end{tabular}


observed. Only in April and beginning of May of 2012 higher mean temperature than in 2010 and 2011 occurred. In our opinion, mean temperature and mean relative humidity did not have any effect on the abundance of weevils collected with pitfall traps in different treatments.

\section{Results and discussion}

Abundance and species composition. In total, 237, 654 and 415 adult weevils were captured by pitfall traps in 2010, 2011 and 2012, respectively (Table 3). In each year, they were the most abundant in the pure stands

Table 3. Number and species composition of weevils collected in narrow-leafed lupin pure stands (A) and intercropped with spring triticale (B and C), during 2010-2012 cropping seasons

\begin{tabular}{|c|c|c|c|c|c|c|c|c|c|c|c|c|}
\hline \multirow{2}{*}{ Species } & \multicolumn{3}{|c|}{2010} & \multirow{2}{*}{ Total } & \multicolumn{3}{|c|}{2011} & \multirow{2}{*}{ Total } & \multicolumn{3}{|c|}{2012} & \multirow{2}{*}{ Total } \\
\hline & $\mathrm{A}^{*}$ & B & $\mathrm{C}$ & & $\mathrm{A}$ & B & $\mathrm{C}$ & & $\mathrm{A}$ & B & $\mathrm{C}$ & \\
\hline $\begin{array}{l}\text { Charagmus griseus } \\
\text { (Fabricius, 1775) }\end{array}$ & 73 & 19 & 14 & $106(44.7 \%)$ & 293 & 143 & 72 & $508(77.7 \%)$ & 134 & 88 & 91 & $313(75.4 \%)$ \\
\hline $\begin{array}{l}\text { Sitona crinitus } \\
\text { (Herbst, 1795) }\end{array}$ & 58 & 12 & 9 & $79(33.3 \%)$ & 46 & 8 & 8 & $62(9.5 \%)$ & 27 & 7 & 18 & $52(12.5 \%)$ \\
\hline $\begin{array}{l}\text { Charagmus gressorius } \\
\text { (Fabricius, 1792) }\end{array}$ & 18 & 9 & 4 & $31(13.1 \%)$ & 42 & 19 & 7 & $68(10.4 \%)$ & 14 & 9 & 6 & $29(7 \%)$ \\
\hline $\begin{array}{l}\text { Sitona puncticollis } \\
\text { Stephens, } 1831\end{array}$ & 5 & 1 & 0 & 6 & 2 & 1 & 0 & 3 & 0 & 0 & 0 & 0 \\
\hline $\begin{array}{l}\text { Gronops inaequalis } \\
\text { Boheman, } 1842\end{array}$ & 2 & 2 & 0 & 4 & 1 & 1 & 0 & 2 & 2 & 0 & 0 & 2 \\
\hline $\begin{array}{l}\text { Ceutorhynchus erysimi } \\
\text { (Fabricius, 1787) }\end{array}$ & 2 & 1 & 0 & 3 & 0 & 0 & 0 & 0 & 0 & 0 & 0 & 0 \\
\hline $\begin{array}{l}\text { Bothynoderes affinis } \\
\text { (Schrank, 1781) }\end{array}$ & 1 & 1 & 0 & 2 & 0 & 0 & 0 & 0 & 0 & 0 & 0 & 0 \\
\hline $\begin{array}{l}\text { Sitona ambiguus } \\
\text { Gyllenhal, } 1834\end{array}$ & 1 & 0 & 0 & 1 & 2 & 0 & 0 & 2 & 1 & 1 & 1 & 3 \\
\hline $\begin{array}{l}\text { Sitona humeralis } \\
\text { Stephens, } 1831\end{array}$ & 0 & 0 & 0 & 0 & 0 & 0 & 0 & 0 & 2 & 0 & 1 & 3 \\
\hline $\begin{array}{l}\text { Sitona lepidus } \\
\text { Gyllenhal, } 1834\end{array}$ & 0 & 0 & 0 & 0 & 0 & 0 & 0 & 0 & 0 & 0 & 3 & 3 \\
\hline $\begin{array}{l}\text { Sitona sulcifrons } \\
\text { Gyllenhal, } 1834\end{array}$ & 0 & 1 & 0 & 1 & 0 & 0 & 0 & 0 & 0 & 0 & 0 & 0 \\
\hline $\begin{array}{l}\text { Sitona hispidulus } \\
\text { (Fabricius, 1776) }\end{array}$ & 0 & 0 & 0 & 0 & 0 & 0 & 0 & 0 & 1 & 0 & 0 & 1 \\
\hline $\begin{array}{l}\text { Donus dauci } \\
\text { (Olivier, 1807) }\end{array}$ & 1 & 0 & 0 & 1 & 0 & 1 & 0 & 1 & 0 & 0 & 0 & 0 \\
\hline $\begin{array}{l}\text { Gronops lunatus } \\
\text { (Fabricius, 1775) }\end{array}$ & 0 & 1 & 0 & 1 & 0 & 0 & 0 & 0 & 1 & 0 & 1 & 0 \\
\hline $\begin{array}{l}\text { Hypera arator } \\
\text { (Linnaeus, 1758) }\end{array}$ & 0 & 0 & 1 & 1 & 1 & 1 & 0 & 2 & 0 & 0 & 0 & 0 \\
\hline $\begin{array}{l}\text { Stenocarus ruficornis } \\
\text { (Stephens, 1831) }\end{array}$ & 0 & 0 & 1 & 1 & 0 & 0 & 0 & 0 & 0 & 0 & 0 & 0 \\
\hline $\begin{array}{l}\text { Sitona sulcifrons } \\
\text { Gyllenhal, } 1834\end{array}$ & 0 & 0 & 0 & 0 & 1 & 0 & 1 & 2 & 0 & 0 & 0 & 0 \\
\hline $\begin{array}{l}\text { Bothynoderes affinis } \\
\text { (Schrank, 1781) }\end{array}$ & 0 & 0 & 0 & 0 & 0 & 0 & 1 & 1 & 1 & 0 & 0 & 1 \\
\hline $\begin{array}{l}\text { Hypera suspiciosa } \\
\text { (Herbst, 1795) }\end{array}$ & 0 & 0 & 0 & 0 & 0 & 1 & 0 & 1 & 1 & 0 & 1 & 2 \\
\hline $\begin{array}{l}\text { Trachyphloeus } \\
\text { bifoveolatus } \\
\text { (Beck, 1817) }\end{array}$ & 0 & 0 & 0 & 0 & 0 & 0 & 0 & 0 & 1 & 0 & 1 & 2 \\
\hline $\begin{array}{l}\text { Marmaropus besseri } \\
\text { Gyllenhal, } 1837\end{array}$ & 0 & 0 & 0 & 0 & 0 & 1 & 0 & 1 & 0 & 0 & 0 & 0 \\
\hline $\begin{array}{l}\text { Otiorhynchus ovatus } \\
\text { (Linnaeus, 1758) }\end{array}$ & 0 & 0 & 0 & 0 & 1 & 0 & 0 & 1 & 1 & 0 & 0 & 1 \\
\hline $\begin{array}{l}\text { Barypeithes pellucidus } \\
\text { (Boheman, 1834) }\end{array}$ & 0 & 0 & 0 & 0 & 0 & 0 & 0 & 0 & 0 & 0 & 1 & 1 \\
\hline Total number & 161 & 47 & 29 & 237 & 389 & 176 & 89 & 654 & 185 & 106 & 124 & 415 \\
\hline Number of species & 9 & 9 & 5 & 13 & 9 & 9 & 5 & 13 & 12 & 4 & 10 & 13 \\
\hline
\end{tabular}

* - treatments see in Table 1 
of lupin. In terms of the total catch, the tendency was for weevil numbers to decrease with decreasing proportion of lupin in the intercropping system. Only in 2012, more beetles occurred in pitfall traps located in the mixture with the lower proportion of lupin than in the mixture with higher proportion. Among the collected weevils, 23 species were identified in three years of study. However, only 13 species were identified annually. In two of the three years (2010 and 2011), 9 species were found in the pure stands and higher proportion of lupin in the mixture and only 5 species in the system with lower proportion of narrow-leafed lupin. In 2012, 12 species occurred on lupin grown in the pure stands, 4 species in the treatment with the higher rate of lupin seeds $(60)$ and 10 species in the treatment with the lower rate (40). Each year, Charagmus griseus was the dominant species in all the three treatments. As shown in Table 3, this species accounted for $44.7 \%$ in $2010,77.7 \%$ in 2011 and $75.4 \%$ in 2012 of all weevils. Sitona crinitus and Ch. gressorius were also abundant. These dominant species are closely associated with the lupin plants (Ströcker et al., 2011). The genus Sitona Germar, 1817 comprises about 100 species. All of them feed on Fabaceae in both larval and imaginal stages (Velasquez de Castro et al., 2007). It seems that they are well studied worldwide. In Germany, Ch. griseus and Ch. gressorius are also the most frequent pests of lupin crops (Strocker et al., 2011). In the former Soviet Union, 12 species of Sitona were important pests of annual leguminous plants. S. crinitus, S. lineatus and S. griseus caused lupin grain yield reduction (Petrukha, 1970). According to Ferguson (1994), S. lineatus caused some feeding damage on Lupinus albus L. and other Lupinus species in the south of England. During our study the rest of the identified species occurred very rarely in the collected material.

In 2010, the first numerous weevils were caught by pitfall traps at the end of April (Fig. 1). Numerous insects were collected till the last ten days of May. In this period, at three collection dates, significantly more weevils were captured in the pure lupin stands than in those intercropped with triticale at seed ratio 60:160 and 40:240. In the second half of June and the first half of July, no adult weevils were found in the collected material. They appeared again in the last two catches in the second half of July. In this period, the number of recorded insects was similar in the three studied treatments.

In 2011, as in the previous year, the maximum number of weevils occurred early in the season (end of April, May) (Fig. 2). In some collection dates, more than 60 weevils were recorded. At four dates in that period, significantly more weevils were found in pure stands of lupin than in mixtures. In June, a decrease in weevil number was noted. An increase in the number of beetles caught occurred again in the first half of July. In this period, they were also the most abundant in the pure lupin crop.

In 2012, the maximum number of weevils was noted in the first catch in May (Fig. 3). At this date, in plots of pure lupin stands twice as many insects were collected as in the other two treatments. Later in the season, the number of weevils caught slowly decreased. In each treatment, they were the least abundant at the end of lupin growing season (second half of July).

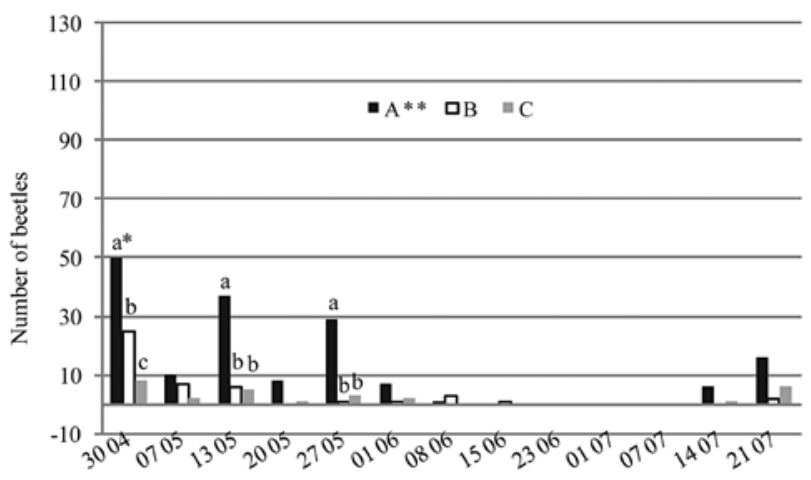

* - different letters show significant differences between treatments (ANOVA, Tukey HSD test, $p \leq 0.05), * *$ - treatments see in Table 1

Figure 1. Population dynamics of weevils in narrowleafed lupin pure stands (A) and intercropped with spring triticale (B and C) in 2010

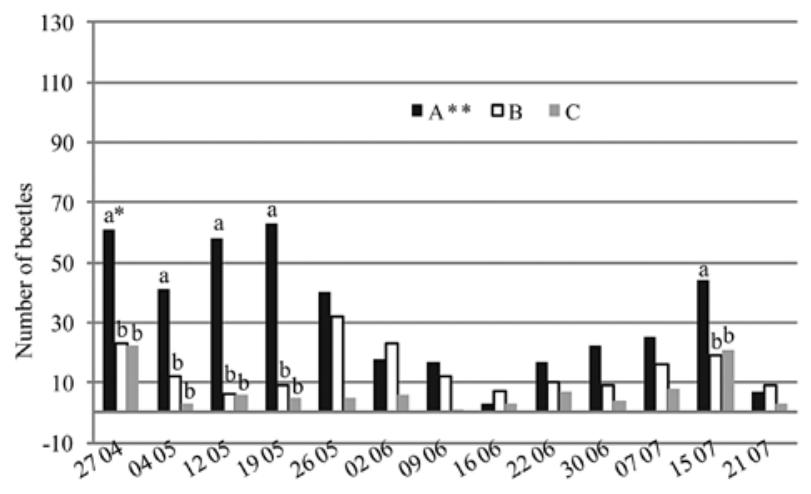

* - explanations see under Figure 1,** - treatments see in Table 1

Figure 2. Population dynamics of weevils in narrowleafed lupin pure stands (A) and intercropped with spring triticale (B and C) in 2011

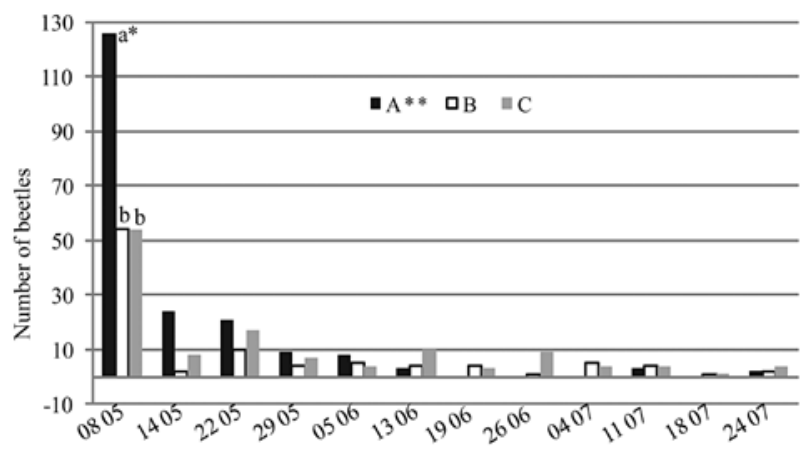

* - explanations see under Figure $1, * *$ - treatments see in Table 1

Figure 3. Population dynamics of weevils in narrowleafed lupin pure stands (A) and intercropped with spring triticale (B and C) in 2012 
Feeding damage. In each year, the number of notches caused by adult weevils on the leaf margins slightly differed between the three treatments. In 2010, the higher number of notches on lupin was observed in two periods, i.e. in May and in the first half of July (Fig. 4). In the first period, the overwintering adult weevils were feeding on lupin at the BBCH stage 13-55. In the second period, new beetles emerged and fed on plants at the $\mathrm{BBCH}$ stage $80-81$. The maximum number of notches in the first period, in each treatment, occurred between $13^{\text {th }}$ and $27^{\text {th }}$ of May. In the second period, the number of notches was distinctly higher than in the first period and their maximum was noted in mid July. In the first half of July, the number of weevils was usually lower than in May but they were actively feeding therefore the number of notches was higher in this period. Only in the last two observations significantly more notches were found in the lupin-triticale mixture than in the single lupin crop. In two intercropping treatments lupin plants were green longer that year, therefore weevils could feed longer.

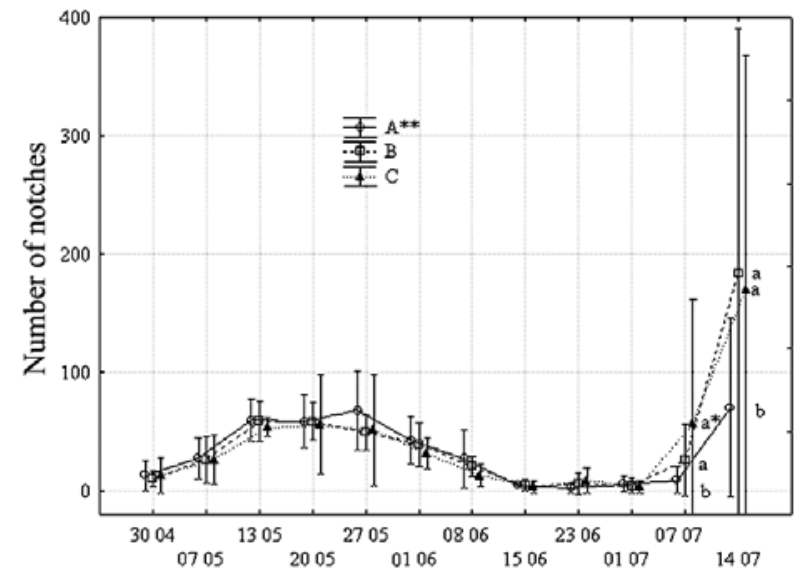

* - explanations see under Figure $1,{ }^{* *}$ - treatments see in Table 1

Figure 4. Number of notches caused by weevils on the leaf margins of lupin plants grown in pure stands (A) and intercropped with spring triticale (B and C) in 2010 (amount \pm standard error)

In 2011, similarly, two periods were distinguished during which the number of notches was higher (Fig. 5). The first such period lasted from the mid May till the first half of June and the second one - from the last days of June till the middle of July. In the first period, plants were at the $\mathrm{BBCH}$ stage 23-73 and in the second period - at the $\mathrm{BBCH}$ stage $75-83$. In the second half of May and in the first half of June, at four out of five observation dates significantly more notches were found on plants growing as pure stand as compared to mixtures. In the second period, many more notches were observed than in the first period, with their maximum number on $7^{\text {th }}$ of July. In this second period, contrary to the first one, more notches were noted on plants growing in mixtures than in the pure stands of lupin. As in the previous year, in the intercropping treatments lupin plants remained green longer and therefore weevils could feed longer on them.

In 2012, the first notches caused by the overwintering adult weevils were observed on lupin plants at the end of April (Fig. 6). From the beginning of May till the end of June (plants at the BBCH stage 1980 ) the feeding damage caused by the beetles was similar in each treatment. At the end of the lupin growing season (plants at the BBCH stage 81-83), the number of notches increased distinctly with their maximum in mid July. As in 2010, new beetles emerging at that time fed actively on lupin. On the last two observations significantly more notches were noted on the plants growing in mixtures as compared to the pure stands.

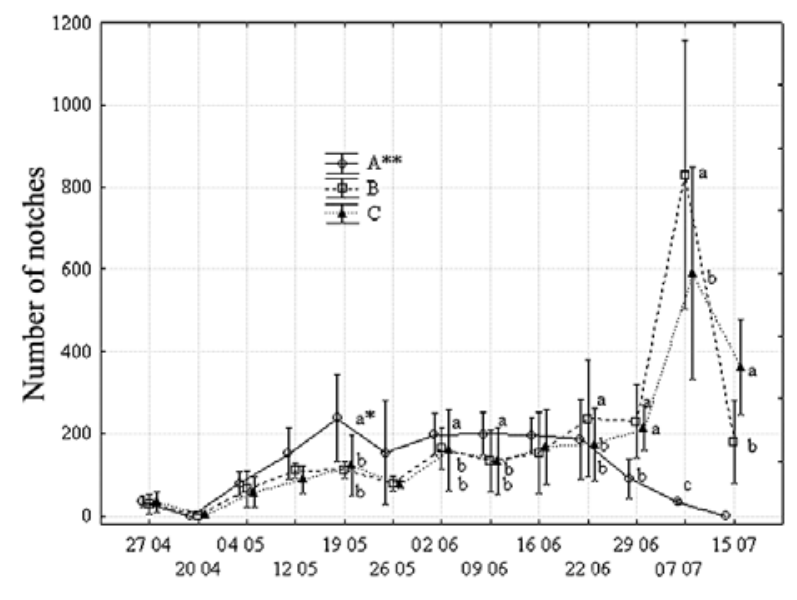

* - explanations see under Figure 1, ** - treatments see in Table 1

Figure 5. Number of notches caused by weevils on the leaf margins of lupin plants grown in pure stands (A) and intercropped with spring triticale (B and C) in 2011 (amount \pm standard error)

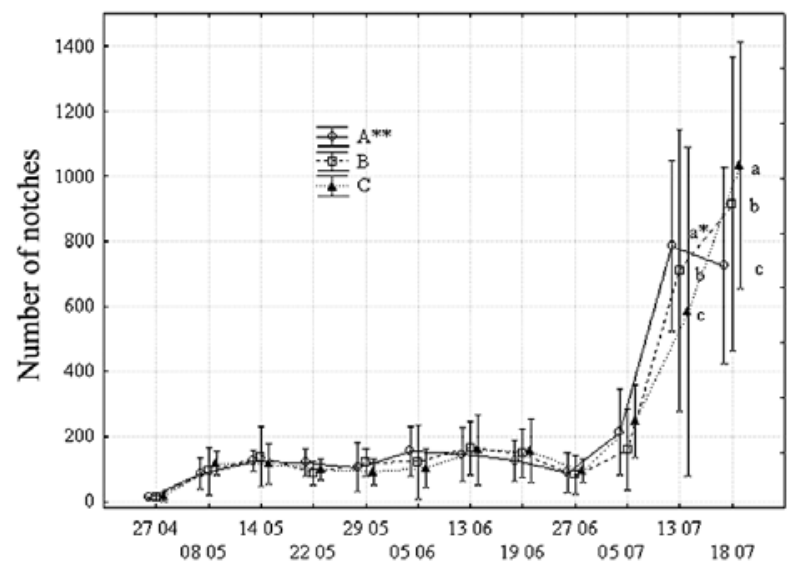

* - explanations see under Figure 1,** - treatments see in Table 1

Figure 6. Number of notches caused by weevils on the leaf margins of lupin plants grown in pure stands (A) and intercropped with spring triticale (B and C) in 2012 (amount \pm standard error) 
It is often stated that intercropping is a habitat management practice that aims at the local reduction of herbivore populations. It is hypothesised that increasing vegetation diversity suppresses herbivore populations by reducing the appearance and quality of crop plants in species mixtures compared to those in monotypic stands (Bukovinszky, 2004). Consequently, plant species mixtures may be used to manage pest problems in agroecosystems, thereby contributing to the development of ecologically sustainable crop production. Andow (1991) shows that the density of insect pest in polyculture system was lower in $52 \%$, equal in $13 \%$ and variable in $20 \%$ of the studied cases in comparison to monocultures. Adults representing Sitona or Charagmus genus are known as the leaf weevils causing serious damage to different leguminous crops, while their larvae can harm the root system of the plants (Petrukha, 1970; Rotrekl, Cejtchaml, 2008; Toshova et al., 2009). Adults feed mainly on the same host plant as the larvae (Velasquez de Castro et al., 2007). Ferguson (1994) reported his on lupin plants in England. In our trials, Ch. griseus was the dominant species, but $S$. crinitus and Ch. gressorius also occurred in greater numbers. Therefore mainly these species were responsible for the damage observed on the narrow-leafed lupin. We did not find apparent differences in the number of notches caused by weevils on the leaf margins of narrow-leafed lupin plants among the three experimental treatments. So far there are no similar studies worldwide on the weevil assemblages analysed in the lupin-triticale system. However, it is possible to find some information concerning related crops in the context of curculionid studies in polyculture system. Yet, the achieved results are widely disparate. For example, Wnuk and Wojciechowicz-Żytko (2010) also did not find significant effects of intercropping phacelia with broad bean on weevils. In other similar studies the lower number of adults and larvae of the analysed beetles was documented in the case of intercropping pea with white mustard in comparison to homogenous habitats of these crops (Wnuk, Wiech, 1996). In turn, Fernandez-Aparicio et al. (2006) in their organic field experiment with faba bean intercropped with triticale or wheat recorded even more damage caused by weevils on legume plants in more diverse habitat. In general, the results obtained in our study indicate that narrow-leafed lupin intercropped with spring triticale also reduced weevil populations, which should be considered as a positive for biological control. Nevertheless, there was no clear relationship between the number of notches and type of cropping system. This could be due to the last observations performed in the experiment, when in the intercropping system lupin plants were more attractive to weevils than in the monoculture.

\section{Conclusions}

1. Weevils were more numerous in the pure stands of narrow-leafed lupin than in those intercropped with spring triticale. Weevil numbers tended to decrease with decreasing proportion of lupin in the intercropping system. The maximum number of beetles occurred early in the season (end of April, May).

2. Twenty one species of weevils were identified in the collected material. Usually more species were found in the pure stands of lupin compared with intercropped ones. In each year, the dominant species in all the three treatments was Charagmus griseus. Sitona macularius and Ch. gressorius were also abundant.

3. The seasonal fluctuations of the number of notches caused by weevil beetles on the leaf margins were similar in all treatments, irrespective of the lupin proportion in the intercropping system. In each year, the number of notches at the end of the lupin growing season was higher in lupin-triticale mixtures than in the single lupin crop. Moreover, in the intercropping treatments the plants of lupin remained green longer; therefore weevils could feed longer on them.

\section{Acknowledgements}

Research was carried out with the financial support of Polish Ministry of Science and Higher Education, under grant NN 310441538. We would like to thank Mr. Andrzej Melke for his support in weevil species identification.

Received 11032013

Accepted 12092013

\section{References}

Altieri M. A. 1999. The biological role of biodiversity in agroecosystems. Agriculture, Ecosystems and Environment, 74: 19-31 http://dx.doi.org/10.1016/S0167-8809(99)00028-6

Altieri M. A., Letourneau D. K. 1982. Vegetation management and biological control in agroecosystems. Crop Protection, 1: $405-430$ http://dx.doi.org/10.1016/0261-2194(82)90023-0

Andow D. 1991. Vegetational diversity and arthropod population response. Annual Review of Entomology, 36: 561-86 http://dx.doi.org/10.1146/annurev.en.36.010191.003021

Andrews D. J., Kassam A. H. 1976. The importance of multiple cropping in increasing world food supplies. Papendick R. I. et al. (eds). Multiple cropping. American Society of Agronomy (special publication), p. 1-11

Bukovinszky T. 2004. Tailoring complexity; multitrophic interactions in simple and diversified habitats. Wageningen University, the Netherlands, $161 \mathrm{p}$.

Ferguson A. W. 1994. Pests and plant injury on lupins in the south of England. Crop Protection, 13: 201-210 http://dx.doi.org/10.1016/0261-2194(94)90079-5 
Fernandez-Aparicio M., Jørnsgård B., Rubiales D. 2006. Effects of crop mixtures on pest of faba bean under organic agritultural conditions. Andalucia J. de (ed.). International Workshop on faba bean breeding and agronomy. Viceconsejeria, Spain, p. 140-142

Hurej M., Twardowski J. 2003. The influence of mixed cropping of yellow lupin and spring triticale on phytophagous and beneficial insects. Zeszyty Problemowe Postępów Nauk Rolniczych, 495: 243-250 (in Polish)

Hurej M., Twardowski J. P. 2006. The influence of yellow lupin intercropped with spring triticale on predatory carabid beetles (Coleoptera: Carabidae). European Journal of Entomology, 103: 259-261

Lithourgidis A. S., Dordas C. A., Damalas C. A., Vlachostgergios D. N. 2011. Annual intercrops: an alternative pathway for sustainable agriculture. Australian Journal of Crop Science, 5: 396-410

Moonen A. C., Bàrberi P. 2008. Functional biodiversity: an ecosystem approach. Agriculture, Ecosystems and Environment, 127: 7-21 http://dx.doi.org/10.1016/j.agee.2008.02.013

Petrukha O. I. 1970. Sitona weevils. Zashchita Rastenii, 15: 24-26

Pisarek M. 2001 (a). The effects of Sitona humeralis larvae on alfalfa Medicago sativa (L.) development. Journal of Plant Protection Research, 41: 52-56

Pisarek M. 2001 (b). The occurrence of Curculionidea on alfalfa (Medicago sativa L.) crops in South-Eastern Poland. Journal of Plant Protection Research, 41: 31-40

Ratnadass A., Fernandes P., Avelino J. 2012. Plant species diversity for sustainable management crop pests and diseases in agroecosystems: a review. Agronomy for Sustainable Development, 32: 273-303 http://dx.doi.org/10.1007/s13593-011-0022-4

Risch S. J. 2005. Intercropping as cultural pest control: prospects and limitations. Environmental Management, 7: 9-14 http://dx.doi.org/10.1007/BF01867035

Rotrekl J., Cejtchaml J. 2008. Control by seed dressing of leaf weevils of the genus Sitona (Col.: Curculionidae) feeding on sprouting alfalfa. Plant Protection Science, 44: 58-64

Silva G. M., De Oliveira A. J. 1959. Experiments on control of pests of the yellow lupin. Agronomia Lusitana, 21: 43-74

Smith H. A., McSorley R. 2000. Intercropping and pest management: a review of major concepts. The American Entomologists, 46: 154-161

Strocker K., Kaufmann K., Schachler B., Struck C. 2011. Influence of insect herbivory on yield and infestation by lupin weevils (Sitona spp.) on different lupin genotypes. Naganowska B. et al. (eds). Lupin crops: an opportunity for today, a promise for the future. Proceedings of the $13^{\text {th }}$ International Lupin Conference. Poznan, Poland, p. $262-268$

Tooker J. F., Frank S. D. 2012. Genotypically diverse cultivar mixtures for insect pest management and increased crop yields. Journal of Applied Ecology, 49: 974-985 http://dx.doi.org/10.1111/j.1365-2664.2012.02173.x

Toshova T. B., Subchev M. A., Atanasova D. I., Velazquez de Castro A. J., Smart L. 2009. Sitona weevils (Coleoptera: Curculionidae) caught by traps in alfalfa fields in Bulgaria. Biotechnology and Biotechnological Equipment, 23: $132-135$
VandermeerJ.H. 1989. The ecology of intercropping. Cambridge, UK http://dx.doi.org/10.1017/CBO9780511623523

Velasquez de Castro A. J., Alonso Zarazaga M. A., Outerelo R. 2007. Systematics of Sitonini (Coleoptera: Curculionidae: Entiminae), with a hypothesis on the evolution of feeding habits. Systematic Entomology, 32: 312-331 http://dx.doi.org/10.1111/j.1365-3113.2006.00368.x

Wnuk A., Wiech K. 1996. The effect of spacing, date of sowing and intercropping on the occurrence of pea pests. Roczniki Nauk Rolniczych, seria E, 25 (1-2): 9-14

Wnuk A., Wojciechowicz-Żytko E. 2010. The influence of intercropping broad bean with phacelia on the occurrence of weevils (Sitona spp.) and broad bean beetles (Bruchus rufimanus Boh.). Folia Horticulare, 22: 33-37 
ISSN 1392-3196 / e-ISSN 2335-8947

Zemdirbyste-Agriculture, vol. 100, No. 4 (2013), p. 393-400

DOI $10.13080 /$ z-a.2013.100.050

\title{
Straubliukų (Coleoptera: Curculionidae) paplitimas siauralapių lubinų grynuose pasėliuose ir mišiniuose su vasariniais kvietrugiais
}

\author{
M. Hurej, J. P. Twardowski, M. Kozak \\ Vroclavo aplinkos ir gyvybės mokslų universitetas, Lenkija
}

\begin{abstract}
Santrauka
Kontroliuojant kenkẻjus svarbi agrotechninė priemonė yra daugianarių pasẻlių auginimas. Ji yra pagrịsta kenkèjų mažinimu didinant ekosistemos įvairovę. Tyrimo tikslas - nustatyti straubliukų gausą ir rūšinę sudètį grynuose lubinų pasėliuose ir mišiniuose su vasariniais kvietrugiais. Straubliukų (Coleoptera: Curculionidae) paplitimas mišiniuose tirtas Vrocavo aplinkos ir gyvybės mokslų universitete Lenkijoje 2010-2012 m. Taikyta skaidytu laukelių tyrimų schema su keturiais pakartojimais kiekvienam augalų mišiniui. Lubinai ir kvietrugiai buvo sèti pagal tris skirtingas sèklų normas. Suaugusių straubliukų gausumas buvo nustatomas naudojant gaudykles. Kiekvieną savaitę registruota žala, suaugusių straubliukų padaryta lubinų augalams maitinimosi metu. Daugiau straubliukų nustatyta grynuose lubinų pasèliuose, palyginus su mišiniais. Daugiau straubliukų rūšių buvo rasta grynuose lubinų pasèliuose nei mišiniuose. Kiekvienais metais dominuojanti sraubliukų rūšis visuose trijuose variantuose buvo Charagmus griseus. Taip pat buvo nustatytas Sitona macularius ir Ch. gressorius gausus paplitimas. Straubliukų lapų kraštams padarytụ pažeidimų skaičiaus sezoniniai svyravimai buvo panašūs visuose variantuose, nepriklausomai nuo lubinų séklų kiekio mišinyje.
\end{abstract}

Reikšminiai žodžiai: kenkèjas, lubinai, mišrūs pasėliai, rūšinė sudėtis, Triticosecale. 